\title{
Lycopene supplementation modulates plasma concentrations and epididymal adipose tissue mRNA of leptin, resistin and IL-6 in diet-induced obese rats
}

\author{
Renata de Azevedo Melo Luvizotto ${ }^{1,2 *}$, Andre F. Nascimento ${ }^{1,2}$, Erika Imaizumi ${ }^{1}$, Damiana T. Pierine ${ }^{2,3}$, \\ Sandro J. Conde ${ }^{1}$, Camila R. Correa ${ }^{3}$, Kyung-Jin Yeum ${ }^{2,4}$ and Ana Lucia A. Ferreira ${ }^{1}$ \\ ${ }^{1}$ Internal Medicine Laboratory, Department of Internal Medicine, Botucatu Medical School, São Paulo State University \\ (UNESP), Distrito Rubiao Jr. s/n, 18618-970 Botucatu, SP, Brazil \\ ${ }^{2} J e a n$ Mayer United States Department of Agriculture, Human Nutrition Research Center on Aging, Tufts University, \\ Boston, MA 02111, USA \\ ${ }^{3}$ Department of Pathology, Botucatu Medical School, São Paulo State University (UNESP), 18618-970 Botucatu, SP, Brazil \\ ${ }^{4}$ College of Biomedical and Health Sciences, Konkuk University, South Korea
}

(Submitted 5 December 2012 - Final revision received 19 March 2013 - Accepted 20 March 2013 - First published online 1 May 2013)

\section{Abstract}

Obesity is characterised by chronic low-grade inflammation, and lycopene has been reported to display anti-inflammatory effects. However, it is not clear whether lycopene supplementation modulates adipokine levels in vivo in obesity. To determine whether lycopene supplementation can regulate adipokine expression in obesity, male Wistar rats were randomly assigned to receive a control diet (C, $n$ 6) or a hyperenergetic diet (DIO, $n$ 12) for 6 weeks. After this period, the DIO animals were randomised into two groups: DIO ( $n$ 6) and DIO supplemented with lycopene (DIO $+\mathrm{L}, n$ 6). The animals received maize oil (C and DIO) or lycopene (DIO $+\mathrm{L}, 10 \mathrm{mg} / \mathrm{kg}$ body weight (BW) per d) by oral administration for a 6-week period. The animals were then killed by decapitation, and blood samples and epididymal adipose tissue were collected for hormonal determination and gene expression evaluation (IL- 6 , monocyte chemoattractant protein-1 (MCP-1), TNF- $\alpha$, leptin and resistin). There was no detectable lycopene in the plasma of the C and DIO groups. However, the mean lycopene plasma concentration was $24 \mathrm{nmol}$ in the DIO + L group. Although lycopene supplementation did not affect BW or adiposity, it significantly decreased leptin, resistin and $I L-6$ gene expression in epididymal adipose tissue and plasma concentrations. Also, it significantly reduced the gene expression of $M C P-1$ in epididymal adipose tissue. Lycopene affects adipokines by reducing leptin, resistin and plasma IL-6 levels. These data suggest that lycopene may be an effective strategy in reducing inflammation in obesity.

Key words: Lycopene: Obesity: Adipokines

Obesity is characterised by chronic low-grade inflammation ${ }^{(1)}$. Its aetiology is multifactorial, and the current epidemic is partially due to the increased availability and consumption of highly palatable diets and reduced energy expenditure ${ }^{(2)}$, which leads to increased adipose tissue. It is recognised as one of the major risk factors for the development of chronic and disabling diseases ${ }^{(3)}$.

White adipose tissue is a dynamic endocrine organ that releases several adipokines and pro-inflammatory factors ${ }^{(4)}$. It has been shown that high levels of pro-inflammatory adipokines in obesity may contribute to the reduction in lipid oxidation in insulin-sensitive organs, leading to lipotoxicity and insulin resistance ${ }^{(5)}$. IL-6 is an important acute-phase mediator with both pro- and anti-inflammatory properties ${ }^{(6)}$, and exhibits many biological functions. In addition to its role as the main acute-phase protein synthesis regulator, it is induced with other cytokines, such as TNF- $\alpha^{(7)}$. TNF- $\alpha$ is a key modulator of adipocyte metabolism, with a direct role in several insulin-mediated processes, including glucose homeostasis and lipid metabolism. High levels of TNF- $\alpha$ are a major contributor to the development of adipose tissue insulin resistance ${ }^{(8)}$. Also, it is associated with significant tissue damage from reactive oxygen species and the promotion of angiogenesis ${ }^{(9)}$. Moreover, elevated TNF- $\alpha$ concentrations and IL-6 have been linked to insulin resistance in obesity ${ }^{(10)}$. In addition, IL- 6 and TNF- $\alpha$ promote leptin production by the adipose tissue, but leptin enhances inflammatory cytokine production as well ${ }^{(5)}$. Hyperleptinaemia is correlated with pro-inflammatory responses and with the chronic subinflammatory state observed in obesity ${ }^{(11)}$. Moreover, leptin

Abbreviations: BW, body weight; C, control; DIO, animals subjected to diet-induced obesity; DIO + L, DIO supplemented with lycopene for 6 weeks; MCP-1, monocyte chemoattractant protein-1.

*Corresponding author: R. A. M. Luvizotto, fax +55 143811 6224, email reluvizotto@yahoo.com 
induces cholesterol uptake by macrophages, angiogenesis and platelet aggregation, and stimulates oxidative stress in endothelial cells, inhibiting vasorelaxation and increasing the risk of atherosclerosis ${ }^{(12)}$. Resistin, another pro-inflammatory adipokine, appears to act through binding to Toll-like receptor 4, a cell-surface receptor and a key component of the inflammatory response to bacterial lipopolysaccharide ${ }^{(13)}$. Located at the site of inflammation, resistin is a molecule that shows a strong correlation with other inflammatory markers, such as IL-6 and TNF- $\alpha^{(14)}$. Also, resistin is associated with decreased insulin sensitivity ${ }^{(13)}$ and seems to be correlated with the development of obesity-related diseases, such as non-alcoholic fatty liver disease ${ }^{(15,16)}$. Studies have suggested that circulating concentrations of pro-inflammatory molecules reflect excess body fat and predispose an individual to a higher risk of developing metabolic diseases ${ }^{(17,18)}$. In addition, the adipose tissue hypersecretion of pro-inflammatory adipokines, such as IL-6, TNF- $\alpha$, leptin and resistin, may play an important role in the pathophysiology of obesity-related complications ${ }^{(19)}$.

Lycopene is a lipophilic carotenoid which is responsible for the red colour in various fruits and vegetables ${ }^{(20)}$ and is commonly found in tomatoes ${ }^{(21)}$. This carotenoid is well known for its antioxidant properties ${ }^{(22-24)}$, and has been reported to display anti-inflammatory effects in adipocytes ${ }^{(25)}$ and liver ${ }^{(26)}$, along with preventing $\mathrm{CVD}^{(27)}$. Evidence is increasing that lycopene or tomato preparations can decrease inflammatory markers ${ }^{(25-28)}$, and may improve diseases with chronic inflammatory backgrounds such as obesity ${ }^{(29)}$. However, the effect of lycopene on pro-inflammatory adipokines, especially leptin and resistin, in obesity has not yet been evaluated.

Since pro-inflammatory adipokines, such as IL-6, TNF- $\alpha$, leptin and resistin, have been linked to adiposity, and lycopene presents anti-inflammatory effects, we hypothesise that lycopene supplementation can modulate epididymal adipose tissue in vivo, reducing the expression of pro-inflammatory cytokines in obesity. The decreased production of these adipokines by lycopene could have a major impact on obesity and the prevalence of obesity-related diseases.

\section{Methods}

\section{Animals and experimental protocol}

Male Wistar rats (10 weeks old, weighing approximately $350 \mathrm{~g}$ ), from the Animal Center of Botucatu Medical School, São Paulo State University, UNESP (Botucatu, SP, Brazil), were initially divided to receive either a commercial chow diet (C, $n$ 6; $12 \%$ energy from fat) or a high-fat diet (49.7\% energy from fat) and sugar in the drinking water $(300 \mathrm{~g} / \mathrm{l})$ (DIO, $n$ 12), for 6 weeks. The high-fat diet was designed in our laboratory to contain a powdered commercial chow diet - NUVILAB CR-1 (Nuvital ${ }^{\circledR}$; Sogorb Indústria e Comércia Ltda), a wafer biscuit, condensed milk, palm oil, vitamins and minerals. The diet-induced obesity model was adapted from our previous study ${ }^{(30)}$, which was used to mimic obesity from Western occidental dietary habits. The nutritional composition of the diets is presented in Table 1 . After 6 weeks under a nutritional overload, DIO rats were randomly
Table 1. Nutritional composition of the diets

\begin{tabular}{|c|c|c|}
\hline \multirow[b]{2}{*}{ Components } & \multicolumn{2}{|c|}{ Diet } \\
\hline & Control & Hyperenergetic \\
\hline Protein (\%) & 25 & 21 \\
\hline Carbohydrate (\%) & 58 & 45 \\
\hline Fat (\%) & 5 & 29 \\
\hline$\%$ Energy from protein & $26 \cdot 5$ & $16 \cdot 0$ \\
\hline$\%$ Energy from carbohydrate & $61 \cdot 5$ & $34 \cdot 3^{\star}$ \\
\hline$\%$ Energy from fat & $12 \cdot 0$ & $49 \cdot 7$ \\
\hline$\%$ Energy from saturated fat & $2 \cdot 1$ & $24 \cdot 7$ \\
\hline$\%$ Energy from unsaturated fat & $9 \cdot 9$ & $25 \cdot 0$ \\
\hline Energy (kcal/g) & 3.77 & $5 \cdot 25$ \\
\hline Energy $(\mathrm{kJ} / \mathrm{g})$ & $15 \cdot 77$ & 21.97 \\
\hline \multicolumn{3}{|l|}{ Fatty acid composition (\%) } \\
\hline Palmitic (16:0) & $14 \cdot 0$ & $40 \cdot 6$ \\
\hline Stearic $(18: 0)$ & $2 \cdot 7$ & $6 \cdot 2$ \\
\hline Oleic $(18: 1 n-9 c)$ & $23 \cdot 4$ & $36 \cdot 5$ \\
\hline Linoleic (18:2n-6) & $53 \cdot 1$ & $11 \cdot 3$ \\
\hline Others & $6 \cdot 8$ & $5 \cdot 4$ \\
\hline Vitamin/mineral mixture $†$ & - & Added \\
\hline
\end{tabular}

* Energy from sugar in the drinking water $(300 \mathrm{~g} / \mathrm{l})$ was not included.

† Based on the vitamin/mineral amounts of the chow diet, for each $\mathrm{kg}$ of the hyperenergetic diet, the following nutrients were added: Fe, $25.2 \mathrm{mg} ; \mathrm{K}, 104.8 \mathrm{mg}$; Se, 73.1 $\mu \mathrm{g}$; molybdenum sulphate, $150.0 \mu \mathrm{g}$; vitamin $B_{12}, 34.5 \mu \mathrm{g}$; vitamin $B_{6}$, $6 \mathrm{mg}$; biotin, $0.12 \mathrm{mg}$; vitamin $\mathrm{E}, 32.6 \mathrm{mg}$; vitamin $\mathrm{D}, 61.2 \mu \mathrm{g}$; vitamin A, $4.6 \mathrm{mg}$.

assigned into two groups: DIO ( $n$ 6) and DIO supplemented with lycopene-rich tomato oleoresin ( DIO $+\mathrm{L}, n$ 6). Tomato oleoresin was mixed with maize oil equivalent to $10 \mathrm{mg}$ lycopene/kg body weight (BW) per $\mathrm{d}^{(31,32)}$ and given orally every morning for a 6 -week period ${ }^{(33,34)}$. To avoid differences in the energy provided, all groups received the same maize oil volume (approximately $2 \mathrm{ml} / \mathrm{kg}$ BW per d). Rats were housed in individual cages in an animal facility at the Internal Medicine Experimental Laboratory, Botucatu Medical School, UNESP, under a controlled ambient temperature $\left(22-26^{\circ} \mathrm{C}\right)$ and lighting ( $12 \mathrm{~h}$ light $-12 \mathrm{~h}$ dark cycle) condition. Dietary consumption was measured daily, and BW was assessed weekly. The animals were killed by decapitation under deep sodium pentobarbital anaesthesia $(50 \mathrm{mg} / \mathrm{kg}$, intraperitoneal injection). Plasma and epididymal adipose tissues were collected at 12 weeks and stored at $-80^{\circ} \mathrm{C}$ until ready for analysis. Epididymal adipose tissue was selected because of its similar inflammation patterns in visceral fat ${ }^{(35)}$. The experiment was conducted in accordance with the Guidelines for the Care and Use of Experimental Animals and the diets followed the specifications from Nutrient Requirements of the Laboratory Rats. The protocol was approved by the local Ethical Committee for Animal Research (protocol no. 920-2012).

\section{Lycopene preparation}

Tomato oleoresin (Lyc-O-Mato 6\% dewaxed; LycoRed Natural Products Industries) was mixed with maize oil and stored at $4^{\circ} \mathrm{C}$ in the dark until used as described previously ${ }^{(24)}$. The tomato oleoresin-maize oil mixture was stirred for $20 \mathrm{~min}$ in a water-bath at $54^{\circ} \mathrm{C}$ before being fed to the animals. Each millilitre of the solution contained $5 \mathrm{mg}$ of total lycopene. Stability of lycopene was monitored at $450 \mathrm{~nm}$, and confirmed by diode-array spectra, as described previously ${ }^{(36)}$. Lycopene 
was stable in the tomato oleoresin-maize oil mixture for 9 weeks at $-20^{\circ} \mathrm{C}$

\section{Total body fat}

Total body fat was measured as the sum of epididymal, retroperitoneal and visceral fat deposits, and was used to calculate the adiposity index ${ }^{(37)}$ to confirm obesity in the animals.

\section{Plasma lycopene analysis}

A $400 \mu \mathrm{l}$ aliquot of plasma was used for lycopene analysis, as described previously ${ }^{(24)}$. Briefly, plasma samples were extracted with $3 \mathrm{ml}$ chloroform-methanol (2:1) followed by $3 \mathrm{ml}$ hexane. The samples were dried under $\mathrm{N}_{2}$ and resuspended in $100 \mu \mathrm{l}$ ethanol, of which $25 \mu \mathrm{l}$ were injected into the HPLC. The results were adjusted by an internal standard containing echinenone. The inter- $(n 3)$ and intra-assay $(n$ 8) $\mathrm{CV}$ was $9 \%$. The recovery of the added internal standard was consistently $>90 \%$. All sample processing and analyses were performed under red light.

\section{Biochemical measurements}

Glucose concentration was assayed from the tip of the tail and determined by using a glucometer (Accu-Chek Go Kit; Roche Diagnostic Brazil Limited). Hormonal concentrations of insulin, leptin, adiponectin (Millipore), resistin (Immuno-Biological Laboratories, Inc.), TNF- $\alpha$ and IL-6 (R\&D Systems, Inc.) were measured by an immunoassay, using a microplate reader (Spectra Max 190; Molecular Devices). The glucose:insulin ratio was used for insulin sensitivity assessment ${ }^{(38)}$.

\section{Gene expression}

Total RNA was extracted from epididymal adipose tissue using the reagent TRIzol (Invitrogen). The SuperScript II First-Strand Synthesis System for RT-PCR (Invitrogen) kit was utilised for the synthesis of $20 \mu \mathrm{l}$ of complementary DNA from $1000 \mathrm{ng}$ of total RNA. The mRNA levels of leptin (assay Rn 00565158_m1; Applied Biosystems), resistin (assay Rn 00595224 m1; Applied
Biosystems), TNF- $\alpha$ (assay Rn 00562055_m1; Applied Biosystems), IL-6 (assay Rn 01410330_m1; Applied Biosystems) and monocyte chemoattractant protein-1 ( $M C P-1$, assay $\mathrm{Rn}$ 00580555_m1; Applied Biosystems) were determined by real-time PCR. Quantitative measurements were made with a commercial kit (TaqMan qPCR; Applied Biosystems) in a detection system (StepOne Plus; Applied Biosystems). Cycling conditions were as follows: enzyme activation at $50^{\circ} \mathrm{C}$ for $2 \mathrm{~min}$, denaturation at $95^{\circ} \mathrm{C}$ for $10 \mathrm{~min}$, complementary DNA products were amplified for forty cycles of denaturation at $95^{\circ} \mathrm{C}$ for $15 \mathrm{~s}$ and annealing/extension at $60^{\circ} \mathrm{C}$ for $1 \mathrm{~min}$. Gene expression was quantified in relation to the values of the C group after normalisation by an internal control (cyclophilin: assay Rn 00690933_m1; Applied Biosystems) by the method $2^{-\Delta \Delta C_{\mathrm{T}}}$, as described previously ${ }^{(39)}$.

\section{Statistical analysis}

Results are expressed as means and standard deviations, and significance of differences were calculated by one-way ANOVA followed by Tukey's post hoc test, using SigmaStat version 3.5 for Windows (Systat Software, Inc.). Differences were considered significant at $P<0 \cdot 05$. Power calculations for the main outcome variables were above $80 \%$.

\section{Results}

\section{Body weight and body fat}

Food intake was reduced in the DIO groups; however, energy intake was similar among the groups. The animals showed the same BW at baseline. At the end of the experiment, the hyperenergetic-fed animals showed a significant BW and adiposity index when compared with control rats. In comparison with the DIO group (Table 2), consumption of the lycopenecontaining maize oil mixture $(\mathrm{DIO}+\mathrm{L})$ did not interfere with BW and the adiposity index (Table 2).

\section{Lycopene uptake and absorption}

In the present study, lycopene was analysed as the total of both cis and all-trans isomers in plasma. Due to the lack of

Table 2. Body weight (BW), dietary intake and adiposity index

(Mean values and standard deviations, $n 6$ )

\begin{tabular}{|c|c|c|c|c|c|c|}
\hline \multirow[b]{3}{*}{ Variables } & \multicolumn{6}{|c|}{ Groups } \\
\hline & \multicolumn{2}{|c|}{ C } & \multicolumn{2}{|c|}{ DIO } & \multicolumn{2}{|c|}{$\mathrm{DIO}+\mathrm{L}$} \\
\hline & Mean & SD & Mean & SD & Mean & SD \\
\hline Initial BW (g) & $341^{\mathrm{a}}$ & 27 & $350^{\mathrm{a}}$ & 31 & $358^{\mathrm{a}}$ & 34 \\
\hline Final BW (g) & $489^{a}$ & 58 & $579^{\mathrm{b}}$ & 71 & $560^{\mathrm{b}}$ & 65 \\
\hline Food intake $(\mathrm{g} / 100 \mathrm{~g}$ BW per $\mathrm{d})$ & $6 \cdot 2^{b}$ & 0.3 & $2 \cdot 5^{\mathrm{a}}$ & 0.1 & $2 \cdot 6^{\mathrm{a}}$ & 0.4 \\
\hline Water intake (ml/100 g BW per d) & $8 \cdot 4^{\mathrm{b}}$ & $1 \cdot 0$ & $7 \cdot 5^{\mathrm{a}, \mathrm{b}}$ & 0.4 & $6 \cdot 5^{\mathrm{a}}$ & 1.2 \\
\hline Energy intake (kcal/100 g BW per d)* & $23 \cdot 6^{\mathrm{a}}$ & 1.2 & $22 \cdot 5^{\mathrm{a}}$ & 0.6 & $21 \cdot 7^{\mathrm{a}}$ & $2 \cdot 3$ \\
\hline Energy intake $(\mathrm{kJ} / 100 \mathrm{~g} \mathrm{BW} \text { per } \mathrm{d})^{*}$ & $98 \cdot 7^{\mathrm{a}}$ & $5 \cdot 0$ & $94 \cdot 1^{a}$ & $2 \cdot 5$ & $90 \cdot 8^{\mathrm{a}}$ & $9 \cdot 6$ \\
\hline Adiposity index (\%) & $5 \cdot 3^{\mathrm{a}}$ & $1 \cdot 2$ & $9 \cdot 5^{\mathrm{b}}$ & $1 \cdot 7$ & $9 \cdot 6^{\mathrm{b}}$ & 1.8 \\
\hline
\end{tabular}

C, control; DIO, animals subjected to diet-induced obesity; DIO + L, DIO supplemented with lycopene for 6 weeks.

${ }^{a, b}$ Mean values with unlike superscript letters were significantly different $(P<0.05$; one-way ANOVA with Tukey's post hoc test).

* Energy intake includes energy from sugar in the drinking water. 
lycopene in the fed diets ${ }^{(24)}$, there was no detectable lycopene in the plasma of the $\mathrm{C}$ or DIO groups. However, after 6 weeks of carotenoid supplementation, lycopene plasma concentrations were evident in the DIO $+\mathrm{L}$ group (Table 3 ).

\section{Insulin sensitivity}

The hyperenergetic diet was associated with a significant increase in glucose and insulin levels when compared with the $\mathrm{C}$ animals, showing reduced insulin sensitivity. Glucose and insulin levels were not modulated by lycopene supplementation. Also, lycopene showed no effect on insulin sensitivity (Table 3).

\section{Adipokine levels}

The consumption of the hyperenergetic diet was associated with a significant increase in inflammatory marker expression, such as $I L-6, M C P-1$ and leptin. However, resistin and $T N F-\alpha$ expression in epididymal adipose tissue showed no difference between the $\mathrm{C}$ and DIO groups. Lycopene supplementation restored the gene expressions of $I L-6, M C P-1$ and leptin to the $C$ levels, while a decreased resistin gene expression in epididymal adipose tissue (Table 4). The plasma levels of TNF- $\alpha$, $I L-6$, leptin and resistin were found to be significantly elevated in the DIO group. Lycopene supplementation significantly decreased leptin levels, and restored the plasma concentrations of $I L-6$ and resistin to the $C$ levels. There was no difference between the DIO and DIO $+\mathrm{L}$ groups in plasma TNF- $\alpha$ concentrations (Table 3). As a recent inflammatory biomarker $^{(40)}$, the leptin:adiponectin ratio was calculated. The DIO group showed an increase in the leptin:adiponectin ratio (C: $0 \cdot 21$ (SD 0.07) $v$. DIO: $1 \cdot 11$ (SD 0.26), $P<0 \cdot 001$ ), while the lycopene-supplemented group presented a lower ratio (DIO: $1 \cdot 11(\mathrm{sD} 0 \cdot 26) v$. DIO + L: 0.56 (SD 0.11), $P<0 \cdot 001)$

\section{Discussion}

Obesity is usually associated with the consumption of hyperenergetic diets and a decrease in energy expenditure ${ }^{(2)}$, resulting in the expansion of the adipose tissue mass and inducing a chronic inflammatory state ${ }^{(19)}$. A high SFA intake from a hyperenergetic diet has been associated with obesity-linked inflammation, and induces inflammationrelated gene expression in adipose tissue ${ }^{(41)}$. In the present study, lycopene displayed anti-inflammatory effects ${ }^{(25,28)}$ in plasma (0.01-0.04 $\mu \mathrm{m})$ after 6 weeks of supplementation in concentrations below the range that can be normally seen in human subjects $(0 \cdot 2-0 \cdot 9 \mu \mathrm{M})^{(42)}$. This can be related mainly to low lycopene bioavailability ${ }^{(42)}$, and also in part to the animals fasting overnight. A previous study has found that a peak accumulation of lycopene in rat plasma occurs between 4 and $8 \mathrm{~h}$ after a single oral administration ${ }^{(43)}$.

Experimental high-fat diet models are considered appropriate to study obesity and its consequences ${ }^{(44)}$. In addition to BW gain, the present experimental model induced an increase in body adiposity from the DIO animals (DIO and $\mathrm{DIO}+\mathrm{L})^{(45,46)}$. As with our recent study ${ }^{(37)}$, animals from the DIO groups consumed smaller dietary amounts and similar energy intakes than those without the treatment ( $\mathrm{C}$ group; Table 2). Even though the protocol devised for the present study was able to induce obesity, it showed that body adiposity is the best indicator of obesity ${ }^{(47)}$. The expansion in weight, and especially body fat, occurs because the augmentation of fat consumption is not accompanied by a proportional increase of fat oxidation. This leads to the deposit of fat as $\operatorname{TAG}^{(48,49)}$ in adipose tissue.

Many studies have demonstrated that white adipose tissue represents an important site of inflammation ${ }^{(1)}$, showing insulin resistance and direct associations between adipose tissue and concentrations of TNF- $\alpha$, IL- 6 and C-reactive protein ${ }^{(17)}$. Here, we demonstrate, in vivo, that the DIO-treated group showed an increase in the epididymal adipose tissue gene expression of $I L-6$ and $M C P-1$ (Table 4) and in the plasma concentrations of IL- 6 and TNF- $\alpha$ (Table 3). Given that mRNA levels do not always represent the protein content, which exerts functional activity, plasma concentration is more relevant than mRNA levels. The divergent data between mRNA levels and plasma concentrations of TNF- $\alpha$ could be explained in part by the stability and translational efficiency

Table 3. Plasma measurements of lycopene, adipokines, glucose, insulin and the glucose:insulin ratio (Mean values and standard deviations, $n 6$ )

\begin{tabular}{|c|c|c|c|c|c|c|}
\hline \multirow[b]{3}{*}{ Variables } & \multicolumn{6}{|c|}{ Groups } \\
\hline & \multicolumn{2}{|c|}{$\mathrm{C}$} & \multicolumn{2}{|c|}{ DIO } & \multicolumn{2}{|c|}{$\mathrm{DIO}+\mathrm{L}$} \\
\hline & Mean & SD & Mean & SD & Mean & SD \\
\hline Lycopene (nmol) & \multicolumn{2}{|c|}{ ND } & \multicolumn{2}{|c|}{ ND } & $23 \cdot 6$ & $10 \cdot 4$ \\
\hline Leptin (ng/ml) & $3 \cdot 7^{\mathrm{a}}$ & $1 \cdot 4$ & $10 \cdot 5^{c}$ & $2 \cdot 2$ & $7 \cdot 4^{b}$ & $1 \cdot 2$ \\
\hline Resistin (ng/ml) & $6 \cdot 3^{a}$ & $2 \cdot 1$ & $10 \cdot 1^{\mathrm{b}}$ & $1 \cdot 8$ & $7 \cdot 5^{a}$ & $1 \cdot 3$ \\
\hline IL-6 (pg/ml) & $136^{a}$ & $5 \cdot 0$ & $150^{b}$ & $7 \cdot 6$ & $132^{\mathrm{a}}$ & $5 \cdot 7$ \\
\hline TNF- $\alpha(p g / m l)$ & $9 \cdot 5^{\mathrm{a}}$ & $3 \cdot 8$ & $16 \cdot 7^{\mathrm{b}}$ & 2.9 & $13 \cdot 9^{a, b}$ & $2 \cdot 8$ \\
\hline Glucose (mg/l) & $952^{a}$ & 82 & $1077^{\mathrm{b}}$ & 50 & $1057^{\mathrm{a}, \mathrm{b}}$ & 122 \\
\hline Insulin (ng/l) & $22^{\mathrm{a}}$ & 4 & $33^{b}$ & 8 & $30^{a, b}$ & 7 \\
\hline Glucose:insulin $\left(\times 10^{-6}\right)$ & $43 \cdot 7^{\mathrm{b}}$ & $5 \cdot 2$ & $34 \cdot 3^{a}$ & $7 \cdot 1$ & $36 \cdot 3^{a, b}$ & $6 \cdot 2$ \\
\hline
\end{tabular}


Table 4. Adipokine mRNA levels in epididymal adipose tissue

(Mean values and standard deviations, $n 6$ )

\begin{tabular}{|c|c|c|c|c|c|c|}
\hline \multirow[b]{3}{*}{ Variables } & \multicolumn{6}{|c|}{ Groups } \\
\hline & \multicolumn{2}{|c|}{ C } & \multicolumn{2}{|c|}{ DIO } & \multicolumn{2}{|c|}{$\mathrm{DIO}+\mathrm{L}$} \\
\hline & Mean & SD & Mean & SD & Mean & SD \\
\hline Leptin & $1.00^{\mathrm{a}}$ & 0.12 & $1 \cdot 31^{b}$ & 0.12 & $0.97^{a}$ & 0.22 \\
\hline Resistin & $1.00^{b}$ & 0.21 & $1.04^{b}$ & 0.17 & $0.56^{a}$ & 0.07 \\
\hline IL-6 & $1.00^{a}$ & 0.25 & $3.00^{b}$ & 0.40 & $0.69^{\mathrm{a}}$ & 0.18 \\
\hline$T N F-\alpha$ & $1.00^{\mathrm{a}}$ & 0.18 & $1 \cdot 22^{\mathrm{a}}$ & 0.16 & $0.97^{\mathrm{a}}$ & 0.18 \\
\hline$M C P-1$ & $1.00^{a}$ & 0.32 & $1.95^{\mathrm{b}}$ & 0.35 & $1.01^{\mathrm{a}}$ & 0.31 \\
\hline
\end{tabular}

C, control; DIO, animals subjected to diet-induced obesity; DIO + L, DIO supplemented with lycopene for 6 weeks; $M C P-1$, monocyte chemoattractant protein-1.

${ }^{\mathrm{a}, \mathrm{b}}$ Mean values with unlike superscript letters were significantly different $(P<0.05$; one-way ANOVA with Tukey's post hoc test).

of $\mathrm{mRNA}^{(9)}$. Similarly, there was a decrease in insulin sensitivity accompanied by an increase in glucose and insulin levels (Table 3). Plasma IL-6 concentrations (Table 3) and the gene expression of $M C P-1$ and $I L-6$ (Table 4) were restored by lycopene supplementation in vivo, which is in agreement with the data of ex vivo and adipocyte models ${ }^{(28)}$. However, plasma $\mathrm{TNF}-\alpha$, glucose and insulin levels and insulin sensitivity (Table 3 ) were not modulated by the 6 weeks of lycopene supplementation in the present study. The probable mechanism that clarifies this lack can in part be explained by increased TNF- $\alpha$. In fact, TNF- $\alpha$ seems to act locally at the site of adipose tissue through autocrine or paracrine pathways, affecting insulin resistance ${ }^{(8)}$ by insulin receptor substrate proteins ${ }^{(50)}$. The processes affecting insulin receptor substrates involve proteasome-mediated degradation, phosphatase-mediated dephosphorylation and Ser phosphorylation of insulin receptor substrate-1, which converts insulin receptor substrate-1 into an inhibitor of the insulin receptor Tyr kinase activity ${ }^{(51,52)}$.

Leptin is a pleiotropic adipocytokine produced and secreted by adipose tissue ${ }^{(11)}$. Experimental studies have suggested that leptin sensitivity may be under hormonal and nutritional con$\operatorname{trol}^{(53)}$. As reported in the studies of diet-induced obesity ${ }^{(54,55)}$, an increase of leptin in epididymal adipose tissue gene expression (Table 4) and plasma levels (Table 3) was found in DIO animals in the present experiment. Previous reports have shown a positive correlation between adipose tissue amounts and the expression of leptin ${ }^{(56,57)}$, indicating that increased levels of leptin result from increased body fat ${ }^{(49)}$. Although there was no change in the adiposity index by lycopene supplementation (Table 2), the present data show that leptin plasma levels were lower in the DIO + L group, possibly by the down-regulation of its gene expression level in epididymal adipose tissue. High levels of leptin can stimulate pro-inflammatory cytokines and play an important role in obesity $^{(11,58)}$. In addition, hyperleptinaemia has been correlated with inflammation levels, since its serum concentration is elevated during active disease (rheumatoid arthritis), and is decreased when the disease is controlled ${ }^{(59,60)}$. Also, a recent study has reported that the leptin:adiponectin ratio is correlated with BMI and may be a useful biomarker for inflammation ${ }^{(40)}$. Here, we demonstrated that the increased leptin:adiponectin ratio in the DIO group was significantly decreased by lycopene supplementation. This suggests inflammatory attenuation associated with lycopene treatment in obese rats. Given that obesity is recognised as a chronic and systemic inflammatory disease ${ }^{(61)}$, the present data suggest that lycopene supplementation may attenuate the inflammatory response in obesity, at least in part, by minimising hyperleptinaemia and improving the leptin:adiponectin ratio.

Resistin concentration has been reported to be increased in obesity $^{(57,62)}$, and to be a link to obesity and insulin resistance $^{(63)}$. The DIO animals did not show an increase in resistin gene expression in epididymal adipose tissue when compared with the $\mathrm{C}$ group (Table 4). However, resistin plasma concentration was greater in the DIO group than in the $\mathrm{C}$ group (Table 3). Increased resistin expression has been correlated with inflammatory markers, coronary artery disease ${ }^{(64)}$ and atherosclerosis in patients with the metabolic syndrome ${ }^{(65)}$. Furthermore, resistin itself has been found to induce the expression of cytokines and chemokines in human articular chondrocytes $^{(66)}$. Also, in patients with gestational diabetes, elevations in serum resistin were correlated with serum IL-6 levels, but not with insulin levels. This suggests that changes in insulin sensitivity in these patients were mediated by inflammatory pathways that may involve resistin ${ }^{(67)}$. Both gene expression and plasma resistin levels were decreased with lycopene supplementation, which has been shown to display anti-inflammatory effects ${ }^{(25,28)}$, suggesting less inflammation in adipose tissue. The exact mechanism of lycopene affecting leptin and resistin levels remains to be determined. To the best of our knowledge, this is the first study which shows that lycopene can modulate both leptin and resistin gene expression and plasma concentrations in obese rats.

In summary, it was observed that lycopene has the ability to down-regulate adipokine mRNA levels in epididymal adipose tissue, such as leptin, resistin, $I L-6$ and $M C P-1$, along with the ability to restore leptin, resistin and plasma IL- 6 concentrations in diet-induced obese rats. Therefore, it is highly probable that lycopene supplementation attenuates inflammation levels in adipose tissue. This could evidence the health effects of this carotenoid. This is the first time that lycopene has been shown to modulate leptin and resistin levels. Therefore, dietary lycopene may be proposed as an effective strategy to reduce inflammation in diet-induced obesity. Although the adopted experimental design did mimic the clinical situation, it gives no information regarding as to whether these findings are applicable to human subjects or not. However, it addresses some important benefits by using additional non-pharmacological therapy that is based on natural compounds in the treatment of human obesity. Moreover, the present study represents a contribution to the role of lycopene on inflammation related to obesity.

\section{Acknowledgements}

We thank Mario B. Bruno, José Carlos Georgette and Renata Capela for their technical support. We appreciate Barbara B. Golner for correcting the English grammar. We are grateful to LycoRed Natural Products Industries, Beer-Sheva, Israel, for 
supplying the tomato oleoresin. We also thank FAPESP (no. 10/06100-9, 10/19746-4, 11/19847-8 and 11/22786-0) for financial support. The authors' contributions were as follows: A. L. A. F., R. A. M. L. and A. F. N. designed the research; R. A. M. L., A. F. N., E. I., D. T. P., S. J. C. and C. R. C. conducted the research; A. F. N. and R. A. M. L. analysed the data; R. A. M. L., K.-J. Y. and A. L. A. F. wrote the paper. All authors read and approved the final manuscript. None of the authors had a personal or financial conflict of interest.

\section{References}

1. Monteiro R \& Azevedo I (2010) Chronic inflammation in obesity and the metabolic syndrome. Mediators Inflamm 2010, $1-10$.

2. Astrup A, Buemann B, Western P, et al. (1994) Obesity as an adaptation to a high-fat diet: evidence from a cross-sectional study. Am J Clin Nutr 59, 350-355.

3. World Health Organization (2011) Obesity and Overweight. Geneva: WHO.

4. Henry SL, Bensley JG, Wood-Bradley RJ, et al. (2012) White adipocytes: more than just fat depots. Int J Biochem Cell Biol 44, 435-440.

5. Zhang H \& Zhang C (2010) Adipose "talks" to distant organs to regulate insulin sensitivity and vascular function. Obesity (Silver Spring) 18, 2071-2076.

6. Tilg H, Trehu E, Atkins MB, et al. (1994) Interleukin 6 (IL-6) as an anti-inflammatory cytokine: induction of circulating IL-1 receptor antagonist and soluble tumor necrosis factor receptor p55. Blood $\mathbf{8 3}, 113-118$.

7. Eklund CM (2009) Proinflammatory cytokines in CRP baseline regulation. Adv Clin Chem 48, 111-136.

8. Arner P (2003) The adipocyte in insulin resistance: key molecules and the impact of the thiazolidinediones. Trends Endocrinol Metab 14, 137-145.

9. Khera TK, Dick AD \& Nicholson LB (2010) Mechanisms of TNF $\alpha$ regulation in uveitis: focus on RNA-binding proteins. Prog Retin Eye Res 29, 610-621.

10. Illán-Gómez F, González-Ortega M, Orea-Soler I, et al. (2012) Obesity and inflammation: change in adiponectin, $C$ reactive protein, tumor necrosis factor-alpha and interleukin-6 after bariatric surgery. Obes Surg 22, 950-955.

11. Fantuzzi G (2005) Adipose tissue, adipokines, and inflammation. J Allergy Clin Immunol 115, 911-919.

12. Rasouli N \& Kern PA (2008) Adipocytokines and the metabolic complications of obesity. J Clin Endocrinol Metab $\mathbf{9 3}$, S64-S73.

13. Tarkowski A, Bjersing J, Shestakov A, et al. (2010) Resistin competes with lipopolysaccharide for binding to Toll-like receptor 4. J Cell Mol Med 14, 1419-1431.

14. Bokarewa M, Nagaev I, Dahlberg L, et al. (2005) Resistin, an adipokine with potent proinflammatory properties. $J$ Immunol 174, 5789-5795.

15. Pagano C, Soardo G, Pilon C, et al. (2006) Increased serum resistin in nonalcoholic fatty liver disease is related to liver disease severity and not to insulin resistance. J Clin Endocrinol Metab 91, 1081-1086.

16. Singhal NS, Patel RT, Qi Y, et al. (2008) Loss of resistin ameliorates hyperlipidemia and hepatic steatosis in leptin-deficient mice. Am J Physiol Endocrinol Metab 295 , E331-E338.

17. Indulekha K, Anjana RM, Surendar J, et al. (2011) Association of visceral and subcutaneous fat with glucose intolerance, insulin resistance, adipocytokines and inflammatory markers in Asian Indians (CURES-113). Clin Biochem 44, 281-287.

18. Stirnadel $\mathrm{H}$, Lin $\mathrm{X}$, Ling $\mathrm{H}$, et al. (2008) Genetic and phenotypic architecture of metabolic syndrome-associated components in dyslipidemic and normolipidemic subjects: the GEMS Study. Atherosclerosis 197, 868-876.

19. Hauner $\mathrm{H}$ (2005) Secretory factors from human adipose tissue and their functional role. Proc Nutr Soc 64, 163-169.

20. Khachik F, Carvalho L, Bernstein PS, et al. (2002) Chemistry, distribution, and metabolism of tomato carotenoids and their impact on human health. Exp Biol Med (Maywood) 227, 845-851.

21. Mangels AR, Holden JM, Beecher GR, et al. (1993) Carotenoid content of fruits and vegetables: an evaluation of analytic data. J Am Diet Assoc 93, 284-296.

22. Di Mascio P, Kaiser S \& Sies H (1989) Lycopene as the most efficient biological carotenoid singlet oxygen quencher. $A r c h$ Biochem Biophys 274, 532-538.

23. Wang S, Konorev EA, Kotamraju S, et al. (2004) Doxorubicin induces apoptosis in normal and tumor cells via distinctly different mechanisms. Intermediacy of $\mathrm{H}_{2} \mathrm{O}_{2^{-}}$and p53-dependent pathways. J Biol Chem 279, 25535-25543.

24. Ferreira ALA, Russell RM, Rocha NS, et al. (2007) Effect of lycopene on doxorubicin-induced cardiotoxicity: an echocardiographic, histological, and morphometrical assessment. Basic Clin Pharmacol Toxicol 101, 16-24.

25. Marcotorchino J, Romier B, Gouranton E, et al. (2012) Lycopene attenuates LPS-induced TNF- $\alpha$ secretion in macrophages and inflammatory markers in adipocytes exposed to macrophage-conditioned media. Mol Nutr Food Res 56, $725-732$.

26. Bignotto L, Rocha J, Sepodes B, et al. (2009) Antiinflammatory effect of lycopene on carrageenan-induced paw oedema and hepatic ischaemia-reperfusion in the rat. Br J Nutr 102, 126-133.

27. Hung CF, Huang TF, Chen BH, et al. (2008) Lycopene inhibits TNF-alpha-induced endothelial ICAM-1 expression and monocyte endothelial adhesion. Eur J Pharmacol 586, $275-282$.

28. Gouranton E, Thabuis C, Riollet C, et al. (2011) Lycopene inhibits proinflammatory cytokine and chemokine expression in adipose tissue. J Nutr Biochem 22, 642-648.

29. Ghavipour M, Saedisomeolia A, Djalali M, et al. (2013) Tomato juice consumption reduces systemic inflammation in overweight and obese females. Br J Nutr 109, 2031-2035.

30. Nascimento AF, Sugizaki MM, Leopoldo AS, et al. (2008) A hypercaloric pellet-diet cycle induces obesity and comorbidities in Wistar rats. Arq Bras Endocrinol Metab 52, 968-974.

31. Ibrahim HS, Ahmed LA \& El-din MME (2008) The functional role of some tomato products on lipid profile and liver function in adult rats. J Med Food 11, 551-559.

32. Ali MM \& Agha FG (2009) Amelioration of spreptozotocin induced diabetes mellitus oxidative stress and dyslipidemia in rats by tomato extract lycopene. Scand J Clin Lab Invest 69, 371-379.

33. Bahcecioglu IH, Kuzu N, Metin K, et al. (2010) Lycopene prevents development of steatohepatitis in experimental nonalcoholic steatohepatitis model induced by high-fat diet. Vet Med Int 2010, 1-8.

34. Wang Y, Ausman LM, Greenberg AS, et al. (2010) Dietary lycopene and tomato extract supplementations inhibit nonalcoholic steatohepatitis-promoted hepatocarcinogenesis in rats. Int J Cancer 126, 1788-1796.

35. Gea-Sorlí S, Bonjoch L \& Closa D (2012) Differences in the inflammatory response induced by acute pancreatitis in 
different white adipose tissue sites in the rat. PLOS ONE 7 , e41933.

36. Yeum KJ, Booth SL, Sadowski JA, et al. (1996) Human plasma carotenoid response to the ingestion of controlled diets high in fruits and vegetables. Am J Clin Nutr 64, 594-602.

37. Nascimento AF, Luvizotto RA, Leopoldo AS, et al. (2011) Long-term high-fat diet-induced obesity decreases the cardiac leptin receptor without apparent lipotoxicity. Life Sci 88, 1031-1038.

38. Coatmellec-Taglioni G, Dausse JP, Ribière C, et al. (2000) Hypertension in cafeteria-fed rats: alterations in renal alpha2-adrenoceptor subtypes. Am J Hypertens 13, 529-534.

39. Livak KJ \& Schmittgen TD (2001) Analysis of relative gene expression data using real-time quantitative PCR and the 2(-Delta Delta C(T)) method. Methods 25, 402-408.

40. Jang AS, Kim TH, Park JS, et al. (2009) Association of serum leptin and adiponectin with obesity in asthmatics. J Asthma 46, 59-63.

41. van Dijk SJ, Feskens EJ, Bos MB, et al. (2009) A saturated fatty acid-rich diet induces an obesity-linked proinflammatory gene expression profile in adipose tissue of subjects at risk of metabolic syndrome. Am J Clin Nutr 90, 1656-1664.

42. Boileau TW, Boileau AC \& Erdman JW (2002) Bioavailability of all-trans and cis-isomers of lycopene. Exp Biol Med (Maywood) 227, 914-919.

43. Mathews-Roth MM, Welankiwar S, Sehgal PK, et al. (1990) Distribution of [14C] canthaxanthin and [14C] lycopene in rats and monkeys. J Nutr 120, 1205-1213.

44. Hariri N \& Thibault L (2010) High-fat diet-induced obesity in animal models. Nutr Res Rev 23, 270-299.

45. Ainslie DA, Proietto J, Fam BC, et al. (2000) Short-term, high-fat diets lower circulating leptin concentrations in rats. Am J Clin Nutr 71, 438-442.

46. Roberts CK, Barnard RJ, Liang KH, et al. (2002) Effect of diet on adipose tissue and skeletal muscle VLDL receptor and LPL: implications for obesity and hyperlipidemia. Atherosclerosis 161, 133-141.

47. Nascimento AF, Sugizaki MM, Leopoldo AS, et al. (2008) Misclassification probability as obese or lean in hypercaloric and normocaloric diet. Biol Res 41, 253-259.

48. Tentolouris N, Pavlatos S, Kokkinos A, et al. (2008) Diet-induced thermogenesis and substrate oxidation are not different between lean and obese women after two different isocaloric meals, one rich in protein and one rich in fat. Metabolism 57, 313-320.

49. Schrauwen P \& Westerterp KR (2000) The role of high-fat diets and physical activity in the regulation of body weight. Br J Nutr 84, 417-427.

50. Hotamisligil GS (2003) Inflammatory pathways and insulin action. Int J Obes Relat Metab Disord 27, Suppl. 3, S53-S55.

51. White MF (2003) Insulin signalling in health and disease. Science 302, 1710-1711.
52. Pirola L, Johnston AM \& Van Obberghen E (2004) Modulation of insulin action. Diabetologia 47, 170-184.

53. Bennet PA, Lindell K, Karlsson C, et al. (1998) Differential expression and regulation of leptin receptor isoforms in the rat brain: effects of fasting and oestrogen. Neuroendocrinology 67, 29-36.

54. López IP, Marti A, Milagro FI, et al. (2003) DNA microarray analysis of genes differentially expressed in diet-induced (cafeteria) obese rats. Obes Res 11, 188-194.

55. Wang M, Orci L, Ravazzola M, et al. (2005) Fat storage in adipocytes requires inactivation of leptin's paracrine activity: implications for treatment of human obesity. PNAS 102, 18011-18016.

56. Frederich RC, Löllmann B, Hamann A, et al. (1995) Expression of ob mRNA and its encoded protein in rodents. Impact of nutrition and obesity. J Clin Invest 96, 1658-1663.

57. Luvizotto RA, Nascimento AF, Síbio MT, et al. (2012) Experimental hyperthyroidism decreases gene expression and serum levels of adipokines in obesity. ScientificWorldJournal 2012, 780890 .

58. Sierra-Honigmann MR, Nath AK, Murakami C, et al. (1998) Biological action of leptin as an angiogenic factor. Science 281, 1683-1686.

59. Lee SW, Park MC, Park YB, et al. (2007) Measurement of the serum leptin level could assist disease activity monitoring in rheumatoid arthritis. Rheumatol Int 27, 537-540.

60. Targonska-Stepniak B, Majdan M \& Dryglewska M (2008) Leptin serum levels in rheumatoid arthritis patients: relation to disease duration and activity. Rheumatol Int 28, 585-591.

61. Gregor MF \& Hotamisligil GS (2011) Inflammatory mechanisms in obesity. Annu Rev Immunol 29, 415-445.

62. Satapathy SK, Ochani M, Dancho M, et al. (2011) Galantamine alleviates inflammation and other obesity-associated complications in high-fat diet-fed mice. Mol Med 17, 599-606

63. Steppan CM, Bailey ST, Bhat S, et al. (2001) The hormone resistin links obesity to diabetes. Nature 409, 307-312.

64. Ohmori R, Momiyama Y, Kato R, et al. (2005) Associations between serum resistin levels and insulin resistance, inflammation, and coronary artery disease. $J$ Am Coll Cardiol $\mathbf{4 6}$ 379-380.

65. Reilly MP, Lehrke M, Wolfe ML, et al. (2005) Resistin is an inflammatory marker of atherosclerosis in humans. Circulation 111, 932-939.

66. Zhang Z, Xing X, Hensley G, et al. (2010) Resistin induces expression of proinflammatory cytokines and chemokines in human articular chondrocytes via transcription and messenger RNA stabilization. Arthritis Rheum 62, 1993-2003.

67. Kuzmicki M, Telejko B, Szamatowicz J, et al. (2009) High resistin and interleukin- 6 levels are associated with gestational diabetes mellitus. Gynecol Endocrinol 25, 258-263. 